\title{
Sex hormones alter the response of Toll-like receptor 3 to its specific ligand in fallopian tube epithelial cells
}

\author{
Zahra Zandieh ${ }^{1,2 *}$, Fatemehsadat Amjadi ${ }^{2,3 *}$, Haghighat Vakilian ${ }^{4}$, Khashayar Aflatoonian ${ }^{5}$, Elham Amirchaghmaghi, ${ }^{6,7}$, \\ Alireza Fazeli ${ }^{8}$, Reza Aflatoonian ${ }^{7}$
}

'Shahid Akbar Abadi Clinical Research Development Unit, Iran University of Medical Sciences, Tehran; '2Department of Anatomy, School of Medicine, Iran University of Medical Sciences, Tehran; ${ }^{3}$ Cellular and Molecular Research Center, School of Medicine, Iran University of Medical Sciences, Tehran; ${ }^{4}$ Department of Nanobiotechnology, Faculty of Biological Sciences, Tarbiat Modares University, Tehran; ${ }^{5}$ School of Medicine, Iran University of Medical Sciences, Tehran; ${ }^{6}$ Department of Regenerative Biomedicine, Cell Science Research Center, Royan Institute for Stem Cell Biology and Technology, ACECR, Tehran; ${ }^{7}$ Department of Endocrinology and Female Infertility, Reproductive Biomedicine Research Center, Royan Institute for Reproductive Biomedicine, ACECR, Tehran, Iran; ${ }^{8}$ Academic Unit of Reproductive and Developmental Medicine, The University of Sheffield, Sheffield, UK

Objective: The fallopian tubes play a critical role in the early events of fertilization. The rapid innate immune defense is an important part of the fallopian tubes. Toll-like receptor 3 (TLR3), as a part of the innate immune system, plays an important role in detecting viral infections. In this basic and experimental study, the effect of sex hormones on the function of TLR3 in the OE-E6/E7 cell line was investigated.

Methods: The functionality of TLR3 in this cell line was evaluated by cytokine measurements (interleukin [IL]-6 and IL-1b) and the effects of sex hormones on TLR3 were tested by an enzyme-linked immunosorbent assay kit. Additionally, TLR3 small interfering RNA (siRNA) and a TLR3 function-blocking antibody were used to confirm our findings.

Results: The production of IL-6 significantly increased in the presence of polyinosinic-polycytidylic acid (poly(l:C)) as the TLR3 ligand. Using a TLR3-siRNA-ransfected OE-E6/E7 cell line and function-blocking antibody confirmed that cytokine production was due to TLR3. In addition, $17-\beta$ estradiol and progesterone suppressed the production of IL-6 in the presence and absence of poly(l:C).

Conclusion: These results imply that sex hormones exerted a suppressive effect on the function of TLR3 in the fallopian tube cell line when different concentrations of sex hormones were present. The current results also suggest that estrogen receptor beta and nuclear progesterone receptor $B$ are likely to mediate the hormonal regulation of TLR3, as these two receptors are the main estrogen and progesterone receptors in OEE6/E7 cell line.

Keywords: Estrogen; Fallopian tube epithelial cells; Innate immunity; Progesterone; Toll-like receptor 3

\section{Introduction}

The fallopian tubes play a critical role in human reproduction. They

Received: Feb 20, 2018 · Revised: Sep 27, 2018 · Accepted: Oct 16, 2018 Corresponding author: Reza Aflatoonian

Department of Endocrinology and Female Infertility, Reproductive Biomedicine Research Center, Royan Institute for Reproductive Biomedicine, ACECR, No. 12, East Hafez Avenue, Bani Hashem St, Resalat Highway, Tehran 16635-148, Iran Tel:+98-21-23562726 Fax:+98-21-23562727 E-mail:R.Aflatoonian@gmail.com

*These authors contributed equally to this study.

This is an Open Access article distributed under the terms of the Creative Commons Attribution Non-Commercial License (http://creativecommons.org/licenses/by-nc/4.0/) which permits unrestricted non-commercial use, distribution, and reproduction in any medium, provided the original work is properly cited. function as sperm reservoirs, and enhance the motility, preserve the viability, and induce capacitation of sperm $[1,2]$. Epithelial cells on the luminal surface of the fallopian tubes provide an optimum environment for the fertilization and early cleavage stage of embryonic development, as they are in direct cell-to-cell contact with gametes and the embryo [3,4]. Therefore, infection within the upper sections of the female reproductive tract, particularly the fallopian tube, can have serious consequences, such as chronic pelvic inflammation, infertility, and pregnancy complications $[5,6]$. Thus, it is crucial that infectious agents be quickly recognized and removed from the upper parts of the female reproductive tract.

Although the physiological roles of the fallopian tubes and the lu- 
minal epithelial cells are well established, insufficient knowledge exists regarding the maintenance of the immune system in this organ. Moreover, it has become clear that the immune system in the fallopian tubes is regulated by the circulating estradiol and progesterone hormones in order to enable the reproductive process that occurs in the fallopian tube to progress [7-9].

The body's first line of defense against infection is the innate immune system. Rapid innate immune defenses against microbial infections usually involve the recognition of invading pathogens by specific pattern recognition receptors, which is attributed to the family of Toll-like receptors (TLRs) [10]. Thirteen members of this group of receptors have been discovered. TLRs 11-13 have been only discovered in mice, not in humans. TLRs 1-10 function in humans and recognize distinct pathogen-associated molecular patterns produced by various bacterial, fungal, and viral pathogens. Toll-like receptor 3 (TLR3) recognizes double-stranded RNA (dsRNA) [11], a molecular signature of RNA viruses [12]. Thus, it is likely that TLR3 plays a physiologic role in antiviral innate immunity $[13,14]$.

dsRNA is produced during RNA viral infection and induces antiviral responses in host cells through a TLR3-mediated signaling pathway. Polyinosinic-polycytidylic acid (poly $(l: C)$ ) is a form of synthetic dsRNA that binds TLR3 and elicits various cellular responses similar to those caused by viral infection $[11,13]$. Furthermore, this synthetic analogue of dsRNA is sensed by TLR3, which also activates adaptive immunity when it is used as a vaccine adjuvant [15]. The induction of TLR3 signaling via dsRNA activates transcription factors such as nuclear factor kappa-B (NFkB) and interferon regulatory factor 3, resulting in the production of proinflammatory and antiviral cytokines [11,16-21].

Numerous studies have demonstrated the existence of this receptor in different parts of the female reproductive tract [22-26]. Additionally, we have documented the expression of TLR3 in various endometrial epithelial cell lines [27]. Several reports have demonstrated the cycle-dependent expression of TLR3 in the endometrium or fallopian tube [28-31]. We also previously demonstrated that TLR3 expression is independent of estradiol and is therefore potentially sustained throughout the menstrual cycle to aid in the defense of the uterus against potential pathogens [32]. Despite many studies in these fields and the importance of the fallopian tube in many physiological and pathological events, few studies have sought to understand the function of TLR3 and its specific role in maintaining innate immunity in the human fallopian tube.

In the present study, we used an immortalized human oviductal epithelial cell line OE-E6/E7 [33] as a model of human fallopian tube epithelium. Our previous study demonstrated that OE-E6/E7 expressed TLR3 through an analysis of messenger ribonucleic acid (mRNA) and protein levels [34]. Therefore, in this study, proinflamma- tory cytokine and chemokine production by these cells was evaluated using a synthetic analogue of dsRNA. To confirm these results, a TLR3-small interfering RNA (siRNA)-transfected OE-E6/E7 cell line was used. Finally, sex hormonal regulation of TLR3 in this cell line and the potential effects of estradiol and progesterone on the function of TLR3 in OE-E6/E7 were also investigated. For further confirmation of our findings, the level of gene expression of $\mathrm{NF \kappa B}$, an important mediator in the TLR3 signaling pathway, was also evaluated.

\section{Methods}

\section{Characterization of TLR3 mRNA expression in OE-E6/E7 cells by reverse-transcription polymerase chain reaction and immunostaining}

TLR3 mRNA expression in the OE-E6/E7 cell line was investigated using reverse-transcription polymerase chain reaction (RT-PCR). OEE6/E7 cells were cultured in a T75 culture dish using regular media as previously described till confluence at $37^{\circ} \mathrm{C}$. At confluence, cells were washed with $\mathrm{Ca}^{2+}$ and $\mathrm{Mg}^{2+}$-free phosphate-buffered saline (PBS) and were harvested using trypsin-ethylenediaminetetraacetic acid (EDTA; Invitrogen, Waltham, MA, USA), pelleted by centrifugation at $300 \times g$ for 5 minutes. One milliliter of TRI reagent (Sigma, St. Louis, MO, USA) was added onto the pellet $\left(5 \times 10^{6}\right.$ cells). Thereafter, total RNA from pelleted cells was extracted following the standard protocol supplied by the manufacturer.

The total RNA obtained from OE-E6/E7 cells was treated with DNase I (DNA-free, Ambion, Huntingdon, UK) to remove genomic DNA contamination from the samples. First-strand complementary DNA (cDNA) synthesis was performed using oligo-dT primers (Metabion, Martinsried, Germany), and reverse transcription was done by SuperScript II (200 U/ $\mathrm{LL}$, Invitrogen). Negative controls were prepared without the enzyme (non-RT controls, RT-negative controls).

PCR was performed with the prepared cDNA, the Platinum Blue PCR Super Mix (Invitrogen), and the appropriate primer sets (Metabion). The forward primer was 5'-GTA TTG CCT GGT TTG TTA ATT GG-3', and the reverse primer was 5'-AAG AGT TCA AAG GGG GCA CT-3', with a product size of $156 \mathrm{bp}$. PCR products were separated on a $1.2 \%$ agarose gel. The amplified PCR products were sequenced to confirm the identity of the amplified product.

For immunostaining, the human fallopian tube epithelial cell line OE-E6/E7 was cultured in 4-well-chamber slides. The antibody (goat polyclonal antibody specific for N-terminal domains of TLR3, catalogue no. sc8691) used in the experiments were obtained from Santa Cruz Biotechnology Inc. (Santa Cruz, CA, USA). Formalin-fixed slides were washed in PBS and then stained using a Vectastain Elite $A B C$ peroxidase kit (Vector Laboratories, Peterborough, UK). Optimum staining was achieved by incubating sections with $10 \mathrm{mg} / \mathrm{mL}$ TLR3 
antibody. Control sections were obtained by omission of the primary antibody. Immunostained sections were examined using an Olympus $\mathrm{BH} 2$ microscope (Olympus, London, UK).

\section{Characterization of TLR3 function in OE-E6/E7 cells}

To study the functionality of TLR3 in OE-E6/E7 cells, they were exposed to the TLR3-specific ligand, poly(l:C), and the levels of interleukin (IL)-1b and IL-6 were detected in the culture media using an enzyme-linked immunosorbent assay (ELISA). Finally, to determine whether cytokine elevation after treatment with poly $(\mathrm{l}: \mathrm{C})$ was mediated via TLR3, a TLR3 siRNA kit (ksirna42-ht|r3, Invitrogen) was used to silence the function of TLR3.

Cells were cultured on 4-well-plate culture dishes until they were confluent. The supernatant was then replaced with $1 \mathrm{~mL}$ of fresh culture medium containing the synthetic TLR3 ligand, poly(l:C) $(25 \mu \mathrm{g} / \mathrm{mL}$; Amersham Biosciences, Piscataway, NJ, USA). Under these conditions, the supernatant was collected 24 hours after stimulation and centrifuged at $300 \times g$ for 5 minutes at $4^{\circ} \mathrm{C}$ and stored at $-70^{\circ} \mathrm{C}$ until used in ELISA. Experiments were performed in triplicate. The concentrations of IL-1b and IL-6 were determined in each supernatant with commercially available ELISA kits (R\&D Systems, Minneapolis, MN, USA).

To determine the role of TLR3 in elevating cytokine levels in response to poly(l:C) in OE-E6/E7 cells, these cells were exposed to TLR3-siRNA. In this procedure, OE-E6/E7 cells were transfected using a recombinant plasmid according to the procedure described in the kit. Two days after transfection, Zeocin $(10 \mu \mathrm{g} / \mathrm{mL})$ was added to the cells and stable transfectants were individualized after 1 week. The OE-E6/E7 cell line that was transfected with TLR3-siRNA was firstly evaluated for TLR3 expression, as indicated by mRNA and protein levels, and then stimulated with poly(l:C) for 24 hours. Thereafter, the concentrations of IL-1b and IL-6 were measured using ELISA. Samples in which no cytokines could be detected were assigned values equivalent to the lower limit of the values detected in the assay (18.75 pg/mL).

For further confirmation, cells were exposed to a TLR3 functionblocking antibody. OE-E6/E7 cells were pretreated with an anti-TLR3 monoclonal antibody (catalogue no. sc-32232, Santa Cruz Biotechnology) at a final concentration of $20 \mu \mathrm{g} / \mathrm{mL}$ for 1 hour at $37^{\circ} \mathrm{C}$, then stimulated with poly $(\mathrm{l}: \mathrm{C})$ for 24 hours. The final concentrations of IL$1 \mathrm{~b}$ and IL-6 were then measured using ELISA.

\section{Determination of the effects of sex hormones on TLR3 function}

To investigate the effect of estradiol and progesterone on the function of TLR3 in OE-E6/E7 cells, these cells were cultured in triplicate in Dulbecco's Modified Eagle's medium (F12). Thereafter, the cells were treated with estradiol and progesterone (Sigma-Aldrich, St. Louis,
MO, USA) at final concentrations of $0,1,10$, and $1,000 \mathrm{nM}$ for estradiol and progesterone in 12-well plates. After 24 hours of treatment with various concentrations of the sex hormones, triplicate wells were stimulated with the TLR3 ligand. Cells were stimulated with poly $(\mathrm{I}: \mathrm{C})$ and the double-stranded DNA negative control, polydeoxyinosinic-deoxycytidylic acid (poly dl:dC; $10 \mu \mathrm{g} / \mathrm{mL}$, Amersham Biosciences). The supernatant of each well was collected after 24 hours of stimulation, centrifuged at $300 \times g$ for 5 minutes at $4^{\circ} \mathrm{C}$, and stored at $-70^{\circ} \mathrm{C}$ until used for ELISA. The concentration of IL- 6 was determined in each supernatant with a commercially available ELISA kit (R\&D Systems).

\section{Evaluation of the effects of sex hormone antagonists on TLR3 function}

For hormone receptor antagonist experiments, cells were pretreated for 2 hours with $1 \mu \mathrm{M} \mathrm{ICl}$ 182, 780 (fulvestrant, an estrogen antagonist; Sigma-Aldrich) or $0.1 \mu \mathrm{M}$ RU486 (mifepristone, a progesterone antagonist; Tocris, St. Louis, MO, USA). Cells were then treated with 10 $\mathrm{nM} 17-\beta$ estradiol or $10 \mathrm{nM}$ progesterone. Triplicate wells were used for each condition. After 24 hours of treatment, the triplicate wells were stimulated with the ligand $(25 \mu \mathrm{g} / \mathrm{mL}$ poly $(\mathrm{l}: \mathrm{C}))$. The supernatant of each well was collected after 24 hours of stimulation and centrifuged at $300 \times g$ for 5 minutes at $4^{\circ} \mathrm{C}$, transferred to fresh tubes, and stored at $-70^{\circ} \mathrm{C}$ until use. The concentration of IL- 6 was again determined in each supernatant using a commercially available ELISA kit (R\&D Systems). For further confirmation, the level of NFKB, an important mediator of TLR3, was also evaluated in each group using RT$\mathrm{PCR}$.

The results were expressed as mean \pm standard error. Statistical analysis was performed using analysis of variance, and the Tukey multiple comparison test was used to determine significant differences between different groups. The $p$-values $<0.05$ were considered to indicate statistical significance.

\section{Results}

\section{TLR3 mRNA and protein presence in OE-E6/E7 using RT-PCR and immunostaining}

Formalin-fixed slides were used to study the distribution of TLR3 in OE-E6/E7 cells. Strong positive immunostaining for TLR3 was observed in the cytoplasm, but not in the cell membrane (Figure 1A). Figure $1 \mathrm{~B}$ shows the results of RT-PCR for mRNA expression of the $T L R 3$ gene in OE-E6/E7 cells. The amplified product was the predicted size for the TLR3 gene. The amplified PCR product was sequenced and confirmed to be the TLR3 gene. No product was amplified in the RT-control samples, indicative of the absence of genomic DNA contamination. 

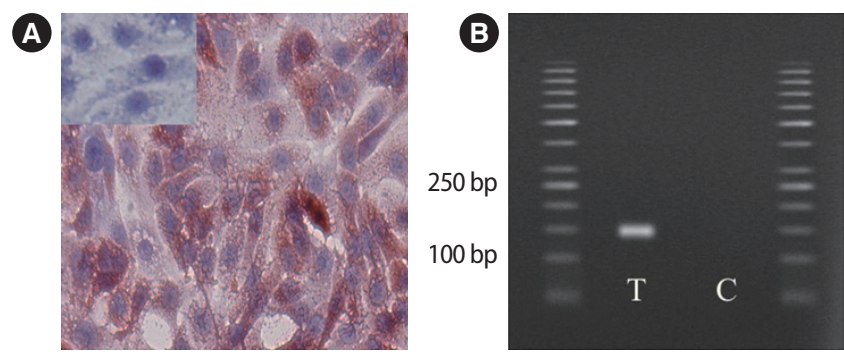

Figure 1. Immunohistochemical staining of Toll-like receptor 3 (TLR3) expression in OE-E6/E7 cells. Positive staining is red and negative staining is blue. Small inserts show blocking of the anti-TLR3 antibodies with the corresponding specific peptide. (A) TLR3 gene expression was positive in this human fallopian tube cell line (OE-E6/E7; magnification, $\times 40$ ). (B) The pair of TLR3 primers produced a specific product with the predicted size in the test $\mathrm{T}$ and control $\mathrm{C}$ samples.
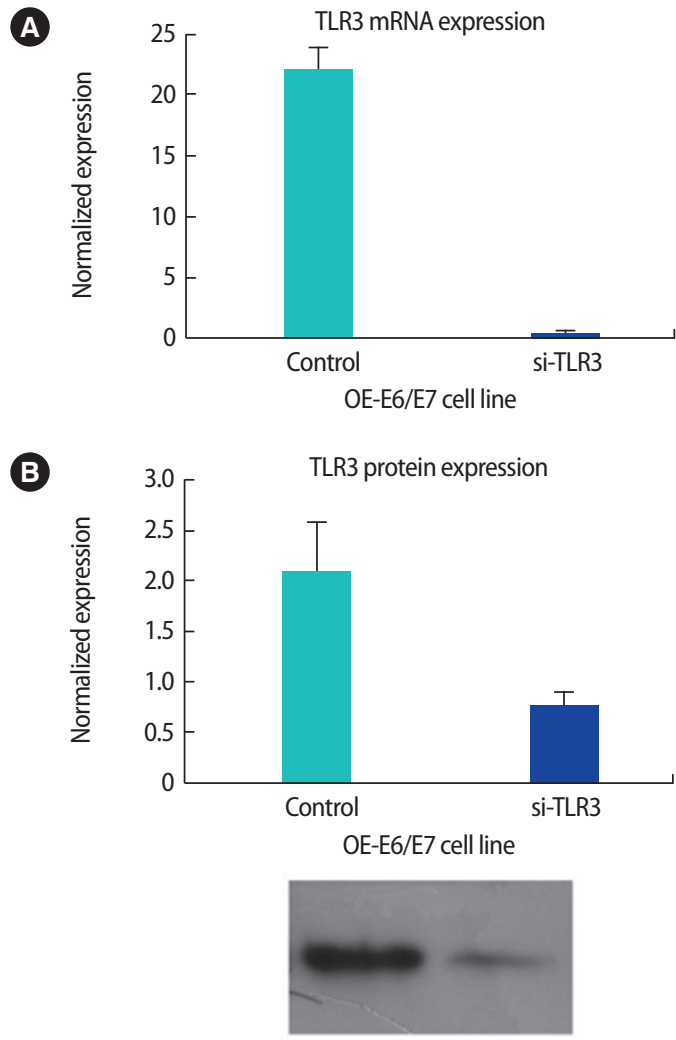

Figure 2. The OE-E6/E7 cells were successfully transfected, as shown in mRNA (messenger ribonucleic acid) level by quantitative polymerase chain reaction $(A)$ and in protein level by Western blot analysis (B). si-TLR3, transfected siRNA for TLR3.

\section{Characterization of TLR3 function in OE-E6/E7 cells with and without TLR3-siRNA and TLR3 function-blocking antibody and determination of the effects of sex hormones on TLR3 function}

Figure 2 shows that the OE-E6/E7 cells were successfully transfect-
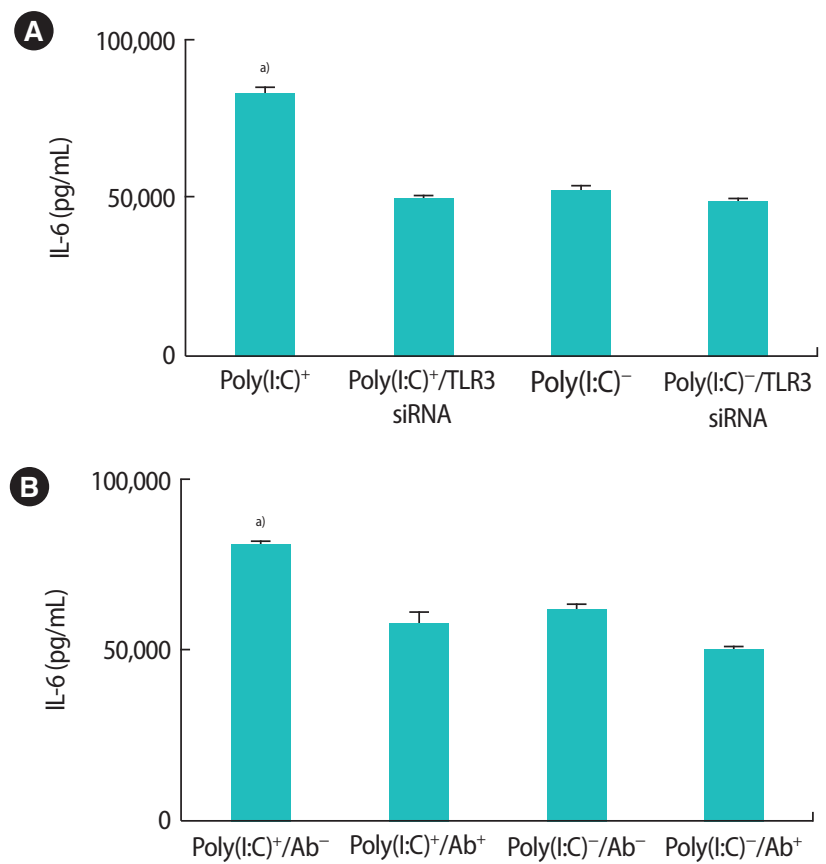

Figure 3. Interleukin (IL)-6 production in the presence of the Toll-like receptor 3 (TLR3)-specific ligand, poly(l:C), in the OE-E6/E7 cell line. TLR3 small interfering RNA (siRNA) (A) and a TLR3 function-blocking antibody $(\mathrm{Ab})(\mathrm{B})$ were used for data confirmation. Poly $(\mathrm{l}: \mathrm{C})$, polyino-

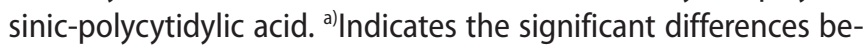
tween groups.

ed, as shown by mRNA and protein levels. The OE-E6/E7 cells did not produce any detectable amount of IL-1b in the presence or absence of the TLR3 ligand. However, the production of IL-6 significantly increased in the presence of the TLR3-specific ligand, poly(l:C) (Figure 3). Using transfected cells with TLR3 siRNA and the TLR3 functionblocking antibody, the increase in the production of IL-6 by poly(l:C) was completely blocked (Figure 3).

The effects of poly $(\mathrm{l}: \mathrm{C})$ and poly(dl:dC) on the production of IL-6 in the presence of 17- $\beta$ estradiol are shown in Figure 4. The production of IL-6 was significantly higher in the presence of poly $(\mathrm{l}: \mathrm{C})$ with different levels of estrogen, in comparison to other conditions (only buffer or only poly(dl:dC) (Figure 4). Additionally, the same effect of the TLR3 ligand on the production of IL- 6 in the presence of different levels of progesterone was observed (Figure 5).

\section{The effect of sex hormone antagonists on TLR3 function}

As depicted in Figure 6, the effects of estrogen and progesterone on the production of IL- 6 were specific. By using $1 \mu \mathrm{M}$ fulvestrant (an estrogen antagonist) 2 hours before estrogen treatment in the culture medium, the suppressive effect of estrogen on the production of IL- 6 was significantly reduced (Figure $6 \mathrm{~A}$ ). Additionally, by using 0.1 $\mu \mathrm{M}$ mifepristone (a progesterone antagonist) 2 hours before proges- 
(A)

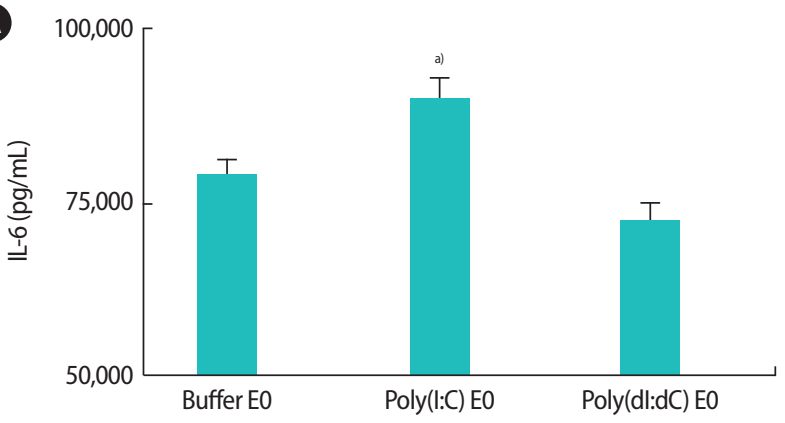

C

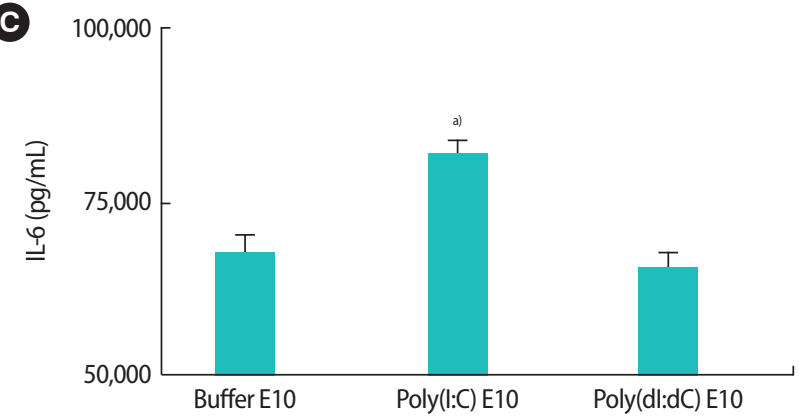

B

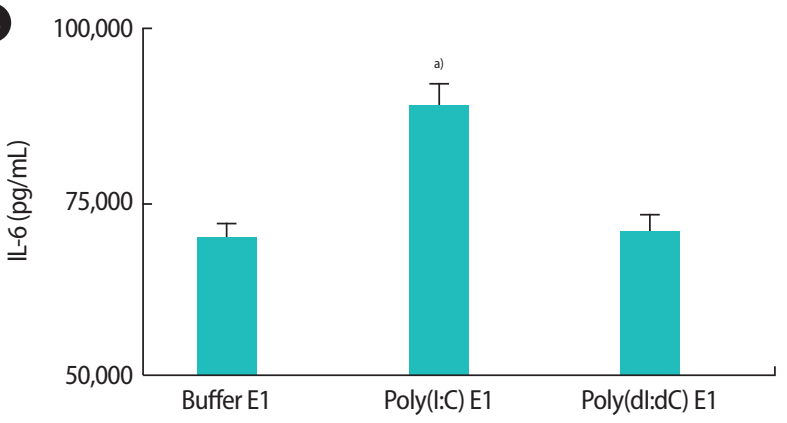

(D)

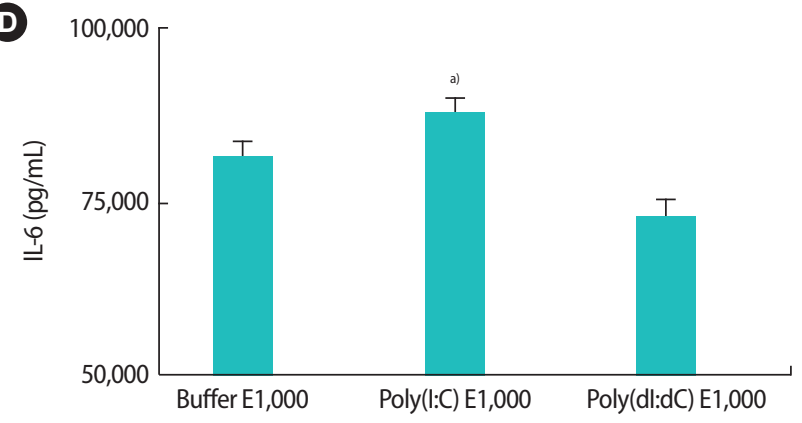

Figure 4. (A-D) The effects of poly $(\mathrm{l}: \mathrm{C})$ and poly $(\mathrm{dl}: \mathrm{dC})$ on the production of interleukin (IL)- 6 in the presence of different concentrations of 17- $\beta$ estradiol (E). Poly(l:C), polyinosinic-polycytidylic acid; Poly(dl:dC), poly(deoxyinosinic-deoxycytidylic) acid. alndicates the significant differences between groups.

A

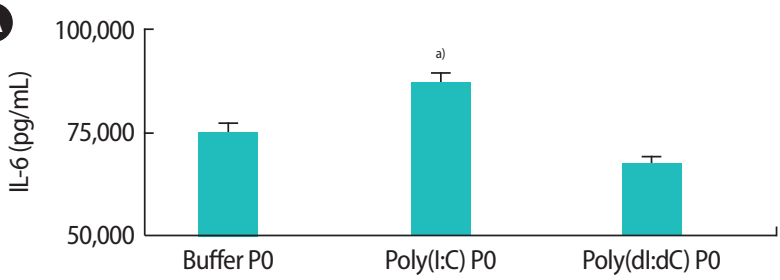

C

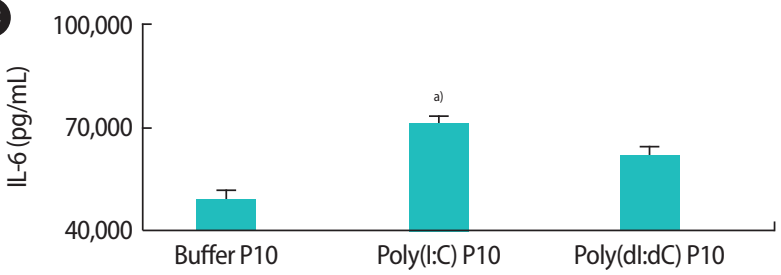

E

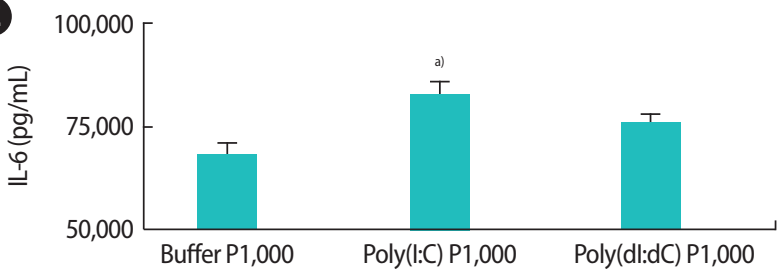

terone treatment, the production of IL- 6 was significantly increased in comparison to progesterone treatment alone (Figure 6B). Figure 7 demonstrates the level of $\mathrm{NFKB}$ mRNA expression in response to fulvestrant and mifepristone. The results show that the level of $\mathrm{NF \kappa B}$ in
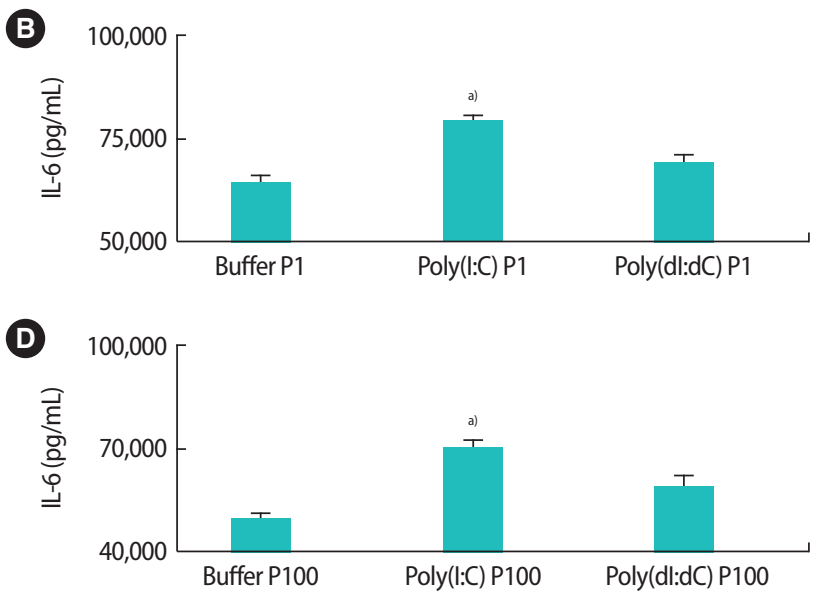

Figure 5. (A-E) The effects of poly $(l: C)$ and poly $(\mathrm{dl}: \mathrm{dC})$ on the production of interleukin (IL)- 6 in the presence of different concentrations of progesterone (P). Poly(l:C), polyinosinic-polycytidylic acid; poly(dl:dC), poly(deoxyinosinic-deoxycytidylic) acid. alndicates the significant differences between groups.

response to mifepristone and fulvestrant before progesterone and estrogen treatment, respectively, was significantly higher than that observed in response to progesterone and estrogen alone. 

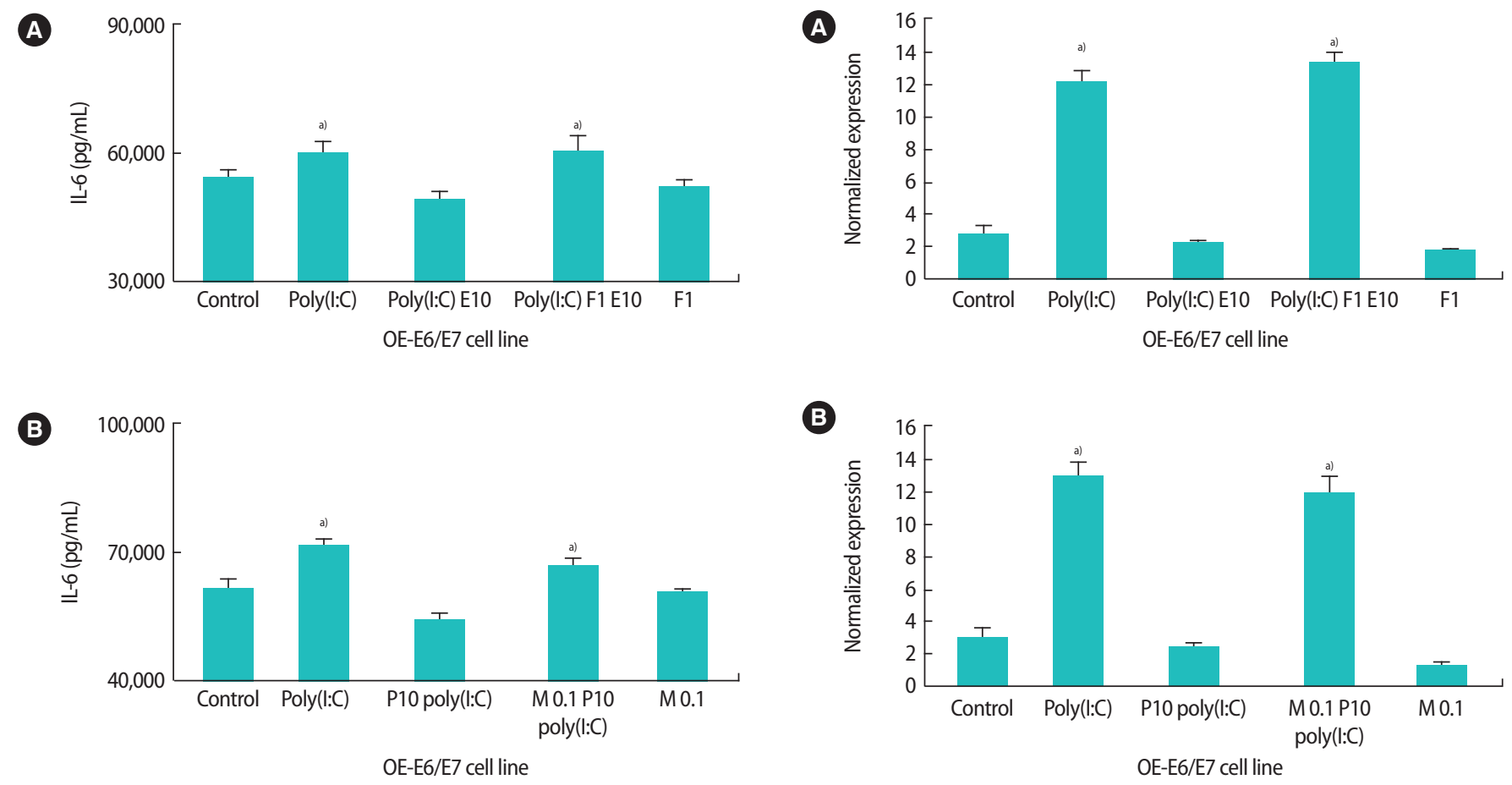

Figure 6. The influence of pretreatment with fulvestrant $(F, A)$ and mifepristone (M, B) on the production of interleukin (IL)- 6 after treatment with $10 \mathrm{nM} 17-\beta$ estradiol (E10) and progesterone (P10) in the presence of poly(l:C). Poly $(\mathrm{l}: \mathrm{C})$, polyinosinic-polycytidylic acid. ${ }^{\text {al }}$ ndicates the significant differences between groups.

\section{Discussion}

The present study characterized the expression and function of TLR3 in this fallopian tube cell line by measuring the production of IL-6 in response to poly(l:C). In addition, we established that both sex hormones suppressed the production of $\mathrm{IL}-6$ in the presence and absence of the TLR3 ligand.

Several studies have examined the presence and the role of TLRs in the female reproductive tract. Nonetheless, the effect of sex hormone regulation on these molecules within the fallopian tube has not been completely identified. Previously, we described the localization of TLR3 in the fallopian tube using immunohistochemistry [23,31]. Pioli et al. [35] demonstrated the presence of TLRs $1-6$ in the female reproductive tract. They also observed the expression of TLR3 mRNA in the fallopian tubes. In addition to our study, which proposed that TLRs are subject to hormonal regulation, as shown by a higher level of the expression of all TLRs during the secretory phase of the menstrual cycle in human endometrium in vivo [28], other reports have investigated the effects of sex hormones on the expression and function of TLRs in the female reproductive tract $[8,25,29,31,32]$. An experiment on uterine epithelial cells demonstrated the presence of a robust interferon beta-mediated response of whole blood cells to poly(l:C), which was

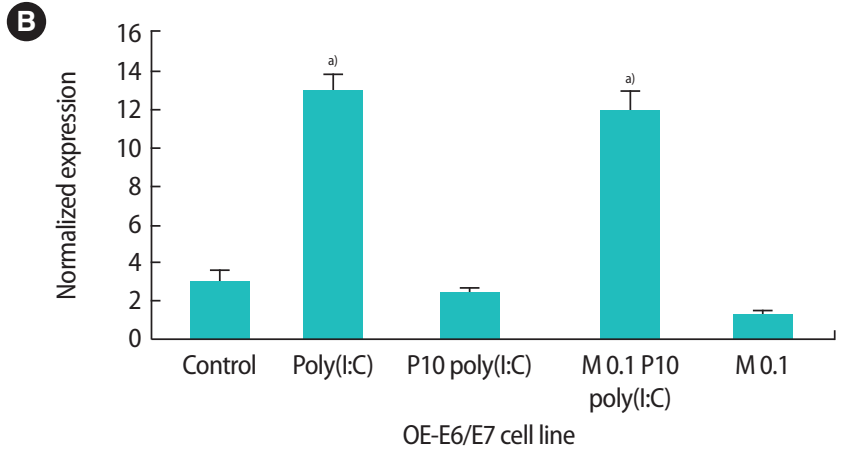

Figure 7. The influence of pretreatment with fulvestrant $(F, A)$ and mifepristone $(M, B)$ on nuclear factor kappa-B (NF $\mathrm{B} B$ ) gene expression after treatment with $10 \mathrm{nM} 17-\beta$ estradiol (E10) and progesterone (P10) in the presence of poly $(\mathrm{l}: \mathrm{C})$. Poly $(\mathrm{l}: \mathrm{C})$, polyinosinic-polycytidylic

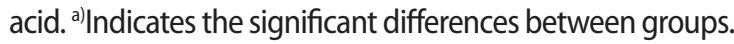

unaffected by estradiol in human uterine epithelial cells [32]. Another study of uterine epithelial cells showed that $17-\beta$ estradiol inhibited the TLR-agonist-induced secretion of tumor necrosis factor $\alpha$ and macrophage Inflammatory protein-3 (MIP3a). In addition to, lipopolysaccharide increased IL-6 expression in these cells, and this upregulation by estradiol pretreatment was completely abrogated $[8,36]$. However, few studies have investigated the role of sex hormones in TLR function in the fallopian tube. In our previous study, we demonstrated in a study using the OE-E6/E7 cell line that the combination of estradiol and progesterone modulated TLR expression [31] and showed that TLR3 is expressed in the human oviduct and that estradiol suppressed TLR3-induced cytokine and chemokine production in human endometrial epithelial cells. Wira et al. [8] showed that sex hormones suppressed the innate, humoral, and cell-mediated immune system in the upper and lower parts of the female reproductive tract. Although none of these studies were done on the fallopian tube, they almost completely agree with our results that innate immunity is modulated by estradiol and progesterone.

TLR3 is activated by dsRNA and plays an important role in the innate immune response directed against dsRNA viral pathogens by coupling to Toll/interleukin-1 receptor domain-containing adapter protein-dependent signal transduction pathways [11,37]. TLR3 can 
mediate responses to the synthetic analogue of viral dsRNA, poly(l:C), which has been used extensively in experimental studies to mimic viral infection [11]. Ank et al. [38] have suggested that type III interferon targets a specific subset of cells, contributing to the antiviral response evoked by TLR3. It has been assumed that TLR3 plays a key role in antiviral immunity against a variety of viruses [39]. In murine oviductal epithelial cells, data implicate TLR3 as an essential inducer of interferon-beta and other inflammatory mediators by epithelial cells during Chlamydia infection, highlighting the contribution of TLR3 to the inflammatory cytokine response [40].

IL-6 is one of the key mediators that orchestrate host immunoinflammatory responses to viral infections [10]. In this study, we showed that estrogen and progesterone exerted a suppressive effect on the production of IL-6 in the presence and absence of the TLR3 ligand. Interestingly, a study investigating IL-6 expression in mouse and human fallopian tube epithelium, showed that 17- $\beta$ estradiol suppressed the expression of IL-6 receptors present in the cilia of epithelial cells [41].

The nuclear estrogen receptor alpha (ERa) [42] was long considered to be the only estrogen receptor and thus responsible for all actions of estrogen. Since the discovery of the second nuclear estrogen receptor, ER [43], it has become evident that ERa and ER $\beta$ not only are encoded by separate genes, but also possess different functions and transcriptional activity [44-46]. In the rat oviduct epithelium, only the ERa subtype is expressed [47], while immunolocalization studies in humans have demonstrated the presence of both estrogen receptors (ERa and ER $\beta$ ) in fallopian tube epithelial cells [48]. Our published data indicate that ER $\beta$ is the only nuclear receptor for estrogen expressed in the OE-E6/E7 cell line [49]. In the present study, we used fulvestrant, which is an antagonist of both ERa and ER $\beta$, to investigate whether the suppressive effect of estrogen on TLR3 function was mediated by estrogen receptors. Considering that only ER $\beta$ seems to be present in this cell line, and the fact that in the presence of fulvestrant, estrogen was no longer capable of inhibiting TLR3 function, $E R \beta$ is likely to mediate the hormonal regulation of TLR3. However, given the complexity of estrogen signaling and its modulation in vivo, direct conclusions regarding the ERß-mediated regulation of TLRs in humans in vivo cannot be drawn based on our data, and further investigations are needed. In recent years, the evaluation of estrogen signaling pathways has become more complicated than ever, as completely novel aspects of estrogen signaling have emerged. A number of reports have provided evidence of functional $\mathrm{G}$ protein-coupled receptors for estrogen [50-52]. Some of these studies have reported receptor localization on the plasma membrane [52], while others, unexpectedly, have found these receptors to be present in the endoplasmic reticulum [51]. Clearly, more studies are needed to clarify the role of these classes of estrogen recep- tors in reproductive physiology. Nonetheless, our data strongly point to the modulation of TLR3 function by ER $\beta$ in fallopian tube epithelial cells.

We previously showed that the membrane receptors for progesterone ( $m P R a$ and $m P R \beta$ ) were both expressed in the OE-E6/E7 cell line. However, the expression level of mPR $\beta$ was very low. Additionally, the nuclear PR-B receptor subtype was found to be expressed in these cells, as well as a PCR product common to the PR-A and PR-B subtypes. The expression level of PR-A,B and PR-B was very similar [49]. Thus, we concluded that PR-B is primarily present in the OE-E6/ $E 7$ line. In the present investigation, we used mifepristone, which is a progesterone nuclear receptor antagonist that can block both PR-A and PR-B, as well as nuclear corticosteroid receptors. Considering that only $\mathrm{mPRa}$ and nuclear PR-B receptors generally seem to be present in this cell line, the fact that in the presence of mifepristone as a progesterone nuclear receptor antagonist, progesterone was no longer capable of inhibiting TLR3 function suggests either that mifepristone can block the function of $\mathrm{mPRa}$ or that this membrane receptor does not mediate the hormonal regulation of TLR3. The current data strongly point to the modulation of TLR3 function by PR-B in fallopian tube epithelial cells.

In conclusion, our study demonstrated that TLR3 function in the human oviductal epithelial cell line OE-E6/E7 is regulated by sex hormones. Clinically, this fact could be quite significant for controlling the immune antiviral response to pathogenic viral infections invading the female reproductive tract. Further experiments should elucidate the regulatory mechanism behind the effect of sex hormones in women, as well as the functional effect that they might have in modulating innate immunity in the human female reproductive tract.

\section{Conflict of interest}

No potential conflict of interest relevant to this article was reported.

\section{Acknowledgments}

We would like to thank Professor Abbas Aflatoonian for his critical views.

\section{References}

1. Fazeli A. Maternal communication with gametes and embryos. Theriogenology 2008;70:1182-7.

2. Lyons RA, Saridogan E, Djahanbakhch O. The reproductive significance of human Fallopian tube cilia. Hum Reprod Update 2006;12:363-72.

3. Georgiou AS, Sostaric E, Wong CH, Snijders AP, Wright PC, Moore 
HD, et al. Gametes alter the oviductal secretory proteome. Mol Cell Proteomics 2005;4:1785-96.

4. Sostaric E, Georgiou AS, Wong CH, Watson PF, Holt WV, Fazeli A. Global profiling of surface plasma membrane proteome of oviductal epithelial cells. J Proteome Res 2006;5:3029-37.

5. Dixon RE, Hwang SJ, Hennig GW, Ramsey KH, Schripsema JH, Sanders KM, et al. Chlamydia infection causes loss of pacemaker cells and inhibits oocyte transport in the mouse oviduct. Biol Reprod 2009;80:665-73.

6. Witkin SS. Immunological aspects of genital chlamydia infections. Best Pract Res Clin Obstet Gynaecol 2002;16:865-74.

7. Ochiel DO, Fahey JV, Ghosh M, Haddad SN, Wira CR. Innate immunity in the female reproductive tract: role of sex hormones in regulating uterine epithelial cell protection against pathogens. Curr Womens Health Rev 2008;4:102-17.

8. Wira CR, Fahey JV, Rodriguez-Garcia M, Shen Z, Patel MV. Regulation of mucosal immunity in the female reproductive tract: the role of sex hormones in immune protection against sexually transmitted pathogens. Am J Reprod Immunol 2014;72:236-58.

9. Hafner LM, Cunningham K, Beagley KW. Ovarian steroid hormones: effects on immune responses and Chlamydia trachomatis infections of the female genital tract. Mucosal Immunol 2013; 6:859-75.

10. Nasu K, Itoh H, Yuge A, Nishida M, Narahara H. Human oviductal epithelial cells express Toll-like receptor 3 and respond to double-stranded RNA: fallopian tube-specific mucosal immunity against viral infection. Hum Reprod 2007;22:356-61.

11. Alexopoulou L, Holt AC, Medzhitov R, Flavell RA. Recognition of double-stranded RNA and activation of NF-kappaB by Toll-like receptor 3. Nature 2001;413:732-8.

12. Bowie AG, Haga IR. The role of Toll-like receptors in the host response to viruses. Mol Immunol 2005;42:859-67.

13. Matsumoto M, Kikkawa S, Kohase M, Miyake K, Seya T. Establishment of a monoclonal antibody against human Toll-like receptor 3 that blocks double-stranded RNA-mediated signaling. Biochem Biophys Res Commun 2002;293:1364-9.

14. Nasu K, Narahara H. Pattern recognition via the Toll-like receptor system in the human female genital tract. Mediators Inflamm 2010;2010:976024.

15. Kumar H, Koyama S, Ishii KJ, Kawai T, Akira S. Cutting edge: cooperation of IPS-1- and TRIF-dependent pathways in poly IC-enhanced antibody production and cytotoxic T cell responses. J Immunol 2008;180:683-7.

16. Doyle S, Vaidya S, O'Connell R, Dadgostar H, Dempsey P, Wu T, et al. IRF3 mediates a TLR3/TLR4-specific antiviral gene program. Immunity 2002;17:251-63.

17. Sato S, Sugiyama M, Yamamoto M, Watanabe Y, Kawai T, Takeda K, et al. Toll/IL-1 receptor domain-containing adaptor inducing IFNbeta (TRIF) associates with TNF receptor-associated factor 6 and TANK-binding kinase 1, and activates two distinct transcription factors, NF-kappa B and IFN-regulatory factor-3, in the Toll-like receptor signaling. J Immunol 2003;171:4304-10.

18. Taniguchi T, Ogasawara K, Takaoka A, Tanaka N. IRF family of transcription factors as regulators of host defense. Annu Rev Immunol 2001;19:623-55.

19. Ghosh M, Schaefer TM, Fahey JV, Wright JA, Wira CR. Antiviral responses of human fallopian tube epithelial cells to toll-like receptor 3 agonist poly(l:C). Fertil Steril 2008;89(5 Suppl):1497-506.

20. Kumar H, Kawai T, Akira S. Pathogen recognition by the innate immune system. Int Rev Immunol 2011;30:16-34.

21. Lund VK, Delotto R. Regulation of Toll and Toll-like receptor signaling by the endocytic pathway. Small GTPases 2011;2:95-8.

22. Aflatoonian $\mathrm{R}$, Fazeli $A$. Toll-like receptors in female reproductive tract and their menstrual cycle dependent expression. J Reprod Immunol 2008;77:7-13.

23. Fazeli A, Bruce C, Anumba DO. Characterization of Toll-like receptors in the female reproductive tract in humans. Hum Reprod 2005;20:1372-8.

24. Fichorova RN, Cronin AO, Lien E, Anderson DJ, Ingalls RR. Response to Neisseria gonorrhoeae by cervicovaginal epithelial cells occurs in the absence of toll-like receptor 4-mediated signaling. J Immunol 2002;168:2424-32.

25. Jorgenson RL, Young SL, Lesmeister MJ, Lyddon TD, Misfeldt ML. Human endometrial epithelial cells cyclically express Toll-like receptor 3 (TLR3) and exhibit TLR3-dependent responses to dsRNA. Hum Immunol 2005;66:469-82.

26. Schaefer TM, Fahey JV, Wright JA, Wira CR. Innate immunity in the human female reproductive tract: antiviral response of uterine epithelial cells to the TLR3 agonist poly(l:C). J Immunol 2005; 174:992-1002.

27. Aboussahoud W, Aflatoonian R, Bruce C, Elliott S, Ward J, Newton S, et al. Expression and function of Toll-like receptors in human endometrial epithelial cell lines. J Reprod Immunol 2010;84:41-51.

28. Aflatoonian R, Tuckerman E, Elliott SL, Bruce C, Aflatoonian A, Li TC, et al. Menstrual cycle-dependent changes of Toll-like receptors in endometrium. Hum Reprod 2007;22:586-93.

29. Hirata T, Osuga Y, Hamasaki K, Hirota Y, Nose E, Morimoto C, et al. Expression of toll-like receptors 2, 3, 4, and 9 genes in the human endometrium during the menstrual cycle. J Reprod Immunol 2007;74:53-60.

30. Lin Z, Xu J, Jin X, Zhang X, Ge F. Modulation of expression of Tolllike receptors in the human endometrium. Am J Reprod Immunol 2009;61:338-45.

31. Zandieh Z, Amjadi F, Ashrafi M, Aflatoonian A, Fazeli A, Aflatoonian 
R. The effect of estradiol and progesterone on Toll like receptor gene expression in a human fallopian tube epithelial cell line. Cell J 2016;17:678-91.

32. Patel MV, Ghosh M, Fahey JV, Wira CR. Uterine epithelial cells specifically induce interferon-stimulated genes in response to polyinosinic-polycytidylic acid independently of estradiol. PLoS One 2012;7:e35654.

33. Lee YL, Lee KF, Xu JS, Wang YL, Tsao SW, Yeung WS. Establishment and characterization of an immortalized human oviductal cell line. Mol Reprod Dev 2001;59:400-9.

34. Zandieh Z, Ashrafi M, Jameie B, Amanpour S, Mosaffa N, Salman Yazdi R, et al. Evaluation of immunological interaction between spermatozoa and fallopian tube epithelial cells. Andrologia 2015;47:1120-30.

35. Pioli PA, Amiel E, Schaefer TM, Connolly JE, Wira CR, Guyre PM. Differential expression of Toll-like receptors 2 and 4 in tissues of the human female reproductive tract. Infect Immun 2004;72:5799-806.

36. Fahey JV, Wright JA, Shen L, Smith JM, Ghosh M, Rossoll RM, et al. Estradiol selectively regulates innate immune function by polarized human uterine epithelial cells in culture. Mucosal Immunol 2008;1:317-25.

37. Yamamoto M, Sato S, Mori K, Hoshino K, Takeuchi O, Takeda K, et al. Cutting edge: a novel Toll/IL-1 receptor domain-containing adapter that preferentially activates the IFN-beta promoter in the Toll-like receptor signaling. J Immunol 2002;169:6668-72.

38. Ank N, Iversen MB, Bartholdy C, Staeheli P, Hartmann R, Jensen UB, et al. An important role for type III interferon (IFN-lambda/IL28) in TLR-induced antiviral activity. J Immunol 2008;180:2474-85.

39. Wang T, Town T, Alexopoulou L, Anderson JF, Fikrig E, Flavell RA. Toll-like receptor 3 mediates West Nile virus entry into the brain causing lethal encephalitis. Nat Med 2004;10:1366-73.

40. Derbigny WA, Shobe LR, Kamran JC, Toomey KS, Ofner S. Identifying a role for Toll-like receptor 3 in the innate immune response to Chlamydia muridarum infection in murine oviduct epithelial cells. Infect Immun 2012;80:254-65.

41. Shao R, Nutu M, Karlsson-Lindahl L, Benrick A, Weijdegard B, Lager $S$, et al. Downregulation of cilia-localized II-6R alpha by 17beta-estradiol in mouse and human fallopian tubes. Am J Physiol Cell Physiol 2009;297:C140-51.

42. Green S, Walter P, Kumar V, Krust A, Bornert JM, Argos P, et al. Human oestrogen receptor cDNA: sequence, expression and homology to v-erb-A. Nature 1986;320:134-9.

43. Kuiper GG, Enmark E, Pelto-Huikko M, Nilsson S, Gustafsson JA. Cloning of a novel receptor expressed in rat prostate and ovary. Proc Natl Acad Sci U S A 1996;93:5925-30.

44. Byers M, Kuiper GG, Gustafsson JA, Park-Sarge OK. Estrogen receptor-beta mRNA expression in rat ovary: down-regulation by gonadotropins. Mol Endocrinol 1997;11:172-82.

45. Critchley HO, Brenner RM, Henderson TA, Williams K, Nayak NR, Slayden OD, et al. Estrogen receptor beta, but not estrogen receptor alpha, is present in the vascular endothelium of the human and nonhuman primate endometrium. J Clin Endocrinol Metab 2001;86:1370-8.

46. Weihua Z, Saji S, Makinen S, Cheng G, Jensen EV, Warner M, et al. Estrogen receptor (ER) beta, a modulator of ERalpha in the uterus. Proc Natl Acad Sci U S A 2000;97:5936-41.

47. Sar M, Welsch F. Differential expression of estrogen receptor-beta and estrogen receptor-alpha in the rat ovary. Endocrinology 1999;140:963-71.

48. Taylor AH, Al-Azzawi F. Immunolocalisation of oestrogen receptor beta in human tissues. J Mol Endocrinol 2000;24:145-55.

49. Monkkonen KS, Aflatoonian R, Lee KF, Yeung WS, Tsao SW, Laitinen JT, et al. Hormonal regulation of Galphai2 and mPRalpha in immortalized human oviductal cell line OE-E6/E7. Mol Hum Reprod 2007; 13:845-51.

50. Benten WP, Stephan C, Lieberherr M, Wunderlich F. Estradiol signaling via sequestrable surface receptors. Endocrinology 2001; 142:1669-77.

51. Revankar CM, Cimino DF, Sklar LA, Arterburn JB, Prossnitz ER. A transmembrane intracellular estrogen receptor mediates rapid cell signaling. Science 2005;307:1625-30.

52. Thomas P, Pang Y, Filardo EJ, Dong J. Identity of an estrogen membrane receptor coupled to a $\mathrm{G}$ protein in human breast cancer cells. Endocrinology 2005;146:624-32. 